\title{
THE DETERMINATION OF SOME POLLUTION PARAMETERS, WATER QUALITY AND HEAVY METAL CONCENTRATIONS OF ACI LAKE (KARAPINAR/KONYA, TURKEY)
}

\author{
Cengiz AKKÖZ * \\ * Selcuk University, Faculty of Science, Akademi Mh. Yeni Istambul Cad. 343, Selcuklu-Konya, \\ Turkey, TR-42130, cakkoz@selcuk.edu.tr
}

DOI: 10.1515/trser-2017-0001

KEYWORDS: Water quality, Heavy metals, pollution, Acı Lake.

\begin{abstract}
Water quality parameters were measured in Ac1 Lake. The measurements were carried out in water samples taken from five different stations over ten months. According to the results of the analyses done on the samples of water, without taking into consideration the differences of seasons and stations, the average annual values of heavy metal concentrations for $\mathrm{Cr}, \mathrm{Cu}$ and $\mathrm{Ni}$ were found to be $0.10 \mathrm{mg} / \mathrm{l}, 0.11 \mathrm{mg} / \mathrm{l}$ and $0.19 \mathrm{mg} / \mathrm{l}$ dry weight, respectively. Surprisingly, Co and Cd metals were not detected at any station or at any season. Other water quality parameters, namely $\mathrm{pH}$, turbidity and nitrate, fall in the intermediate value range for these measures. The comparisons of the measured parameters and the metal concentration with the water quality index show that the water quality of Ac1 Lake prevents the water being used as irrigation water due to high salt levels.
\end{abstract}

ZUSAMMENFASSUNG: Bestimmung einiger Verunreinigungsparameter, der Wassergüte und der Schwermetallkonzentrationen des Aci-Sees (Karapinar/Konya, Türkei).

Im Aci-See wurden die Gewässergüteparameter gemessen. Die Wasserproben wurden innerhalb von zehn Monaten an fünf Probestellen entnommen. Entsprechend den Ergebnissen der untersuchten Wasserproben - ohne Berücksichtigung der jahreszeitlichen und der standörtlichen Unterschiede- wurden die jährlichen Mittelwerte des Schwermetallgehaltes von $\mathrm{Cr}, \mathrm{Cu}$ und Ni mit jeweils $0,10 \mathrm{mg} / \mathrm{l}, 0,11 \mathrm{mg} / \mathrm{l}$ und $0,19 \mathrm{mg} / \mathrm{l}$ Trockengewicht ermittelt. Überraschender Weise wurden die Schwermetalle Co und Cd innerhalb des Untersuchungszeitraumes an keiner der Probestellen vorgefunden. Messungen der pH Werte, der Trübung und Nitrate wurden als zusätzliche Gütewerte hinzugefügt. Der Vergleich der gemessenen Parameter und der Schwermetallkonzentration mit dem Gewässergüte-Index zeigen, dass das Wasser des Aci Sees aufgrund seines hohen Salzgehaltes für Bewässerungszwecke nicht verwendet werden kann.

REZUMAT: Determinarea parametrilor de poluare, calitatea apei și concentrația metalelor grele din lacul Acı (Karapinar/Konya, Turcia).

Parametri de calitate ai apei au fost măsurați pentru lacul Acı. Măsurătorile, au fost realizate pentru probe de apă din cinci stații pe parcursul a zece luni. Rezultatele arată, fără a lua în considerare diferențele sezoniere și stațiile, că valorile medii anuale a concentrațiilor de metale grele precum $\mathrm{Cr}$, $\mathrm{Cu}$ și $\mathrm{Ni}$ sunt următoarele: $0,10 \mathrm{mg} / \mathrm{l}, 0,11 \mathrm{mg} / 1$ și $0,19 \mathrm{mg} / 1 \mathrm{din}$ substanța uscată. Nu au fost observate metale precum Co sau Cd în nici un sezon sau stație. Pe lângă acestea, $\mathrm{pH}$-ul, turbiditates și o concentrația de nitraţi au fost măsurate. Comparația concentrațiilor măsurate cu indicele de calitate al apei arată că apa din lacul Acı nu poate fi acceptată pentru irigare datorită nivelului ridicat de săruri. 


\section{INTRODUCTION}

In many respects, water is one of the most important molecules in the world (Gleick, 1993). Conservation, usage and management of water supplies are therefore extremely important. After tropical jungles, wetlands are the second most important habitat for biological production and biodiversity conservation (Brinson et al., 1981; De Groot et al., 2006; Bănăduc et al., 2016). Especially, drought influence on soil moisture content cause a diminishment in wetlands and finally result in wetland loss, leading to disruption of ecological properties and processes, and a decrease in biodiversity (Poons et al., 2008; Wang et al., 2016). Not only global warming and climate change but also insensitive and uncontrolled industrialization as well as pollution and over-use of water are all causes of wetland loss. (Keddy, 1983)

Intense activity in the industrial and agriculture sectors in Turkey and elsewhere has inevitably led to increases in the levels of heavy metals in natural waters (Karadede et al., 2004). Fish and plants may accumulate large amounts of some metals from water. Accumulation patterns of contaminants in fish and other aquatic organisms depend both on up take and elimination rates (Hakanson, 1984; Karadede et al., 2000). For these reasons, it is important to determine the concentrations of heavy metals in commercial fish in order to evaluate the possible risk of fish consumption for human health (Cid et al., 2001).

The aim of this study is to explore the reasons for the deterioration of the natural resources around Ac1 Lake, Turkey, and especially to explore thoroughly the reasons for the decrease of the water level of the lake. Acı Lake, which is volcanic-based and a salty water source, is an important habitat for birds and other creatures. Thus, through this study, some important precautions will be determined to protect Ac1 Lake, which is classified as one of the most important geological sites and accepted to be an important wetland in the region.

\section{MATERIAL AND METHODS}

\section{Study site}

Ac1 Lake (Figs. 1A-C), which is our research area, is $108 \mathrm{~km}$ north east of the regional capital, Konya and eight km north east of Karapınar, close to the Adana Highway (Fig. 1A). Ac1 Lake is $200 \mathrm{~m}$ deep. The source of the lake is rain and groundwater sources. Water from Ac1 Lake contains sulfur salts, giving it a salty and bitter taste. Ac1 Lake is one of the deepest lakes in the area, and is closest to Konya.

\section{Water sampling method}

In this case study, to determine the level of pollution and the quality of the water in Ac1 Lake, during the years of 2005-2006, monthly water samples (Fig. 2) of the lake were taken. The study was conducted in four different stations chosen from Ac1 Lake, to take the water samples. Samples were taken once a month.

In the previously determined station areas, nearly five $\mathrm{m}$ distant from the shore, water samples were taken and put into $500 \mathrm{ml}$ plastic bottles. $\mathrm{HNO}_{3}$ in the proportion of $65 \%$ were added to the samples that had been taken (Cataldo et al., 2001). The samples, by being put into transport containers, which include ice masses, were protected from external factors such as daylight and heat, and they were brought to the laboratory in this manner within the same day. While the samples of the sediments were kept frozen at $-18^{\circ} \mathrm{C}$ till they are analysed, the samples of water were kept refrigerated at $10^{\circ} \mathrm{C}$. 

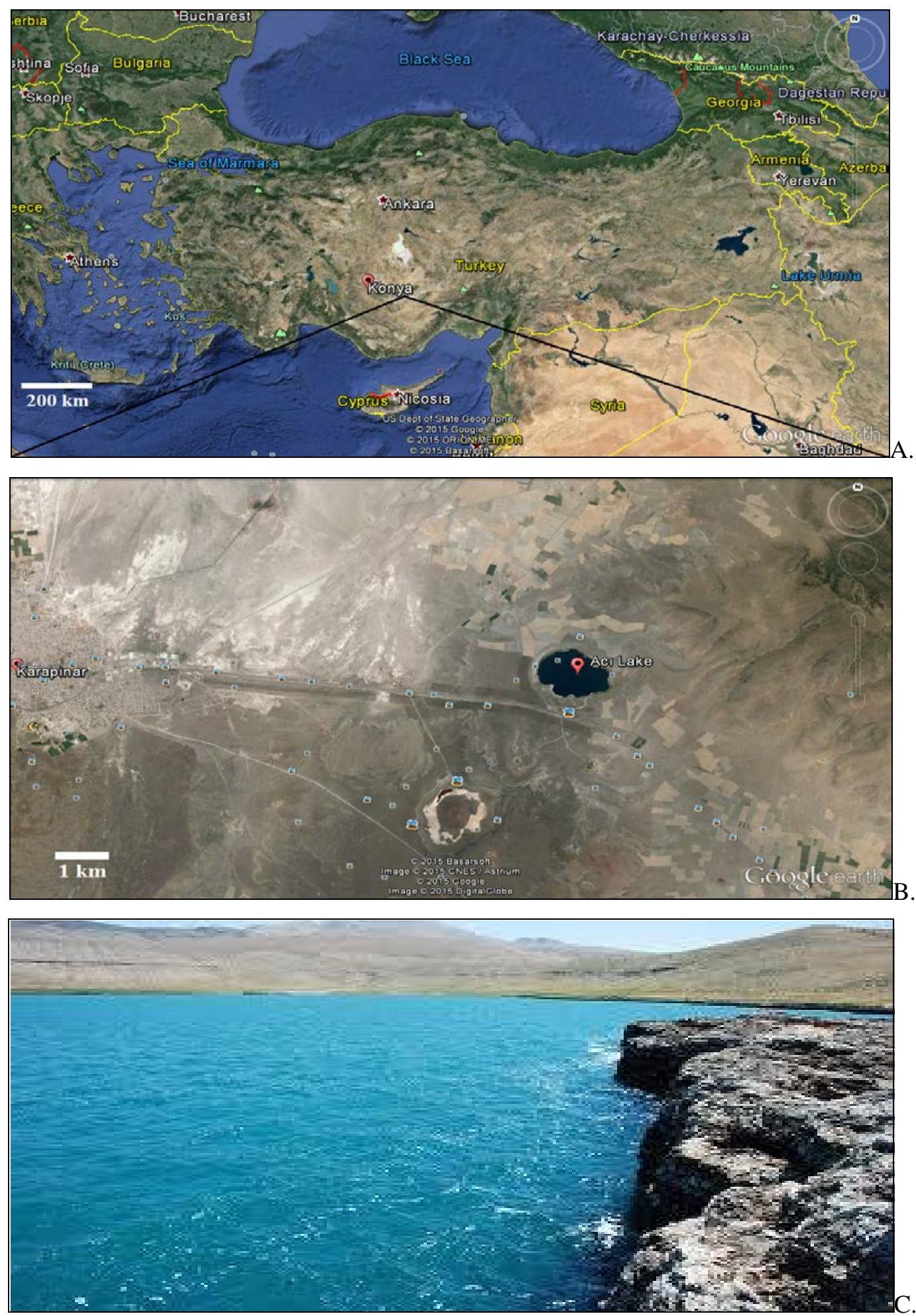

Figure 1: The Ac1 Lake satellite image A (Google Earth), schematic map B and image C. 


\section{Heavy Metal Analysis in the Water Samples}

First and foremost, to prevent cross-contamination, the materials that were used in the study were washed in water prepared with $0.69 \% \mathrm{HNO}_{3}$ and deionized water, and then they were dried in the drying oven. The samples of the water were poured through $100 \mathrm{~mm}$ blue band filter paper into a Falcon tube until a volume of $25 \mathrm{ml}$ was reached.

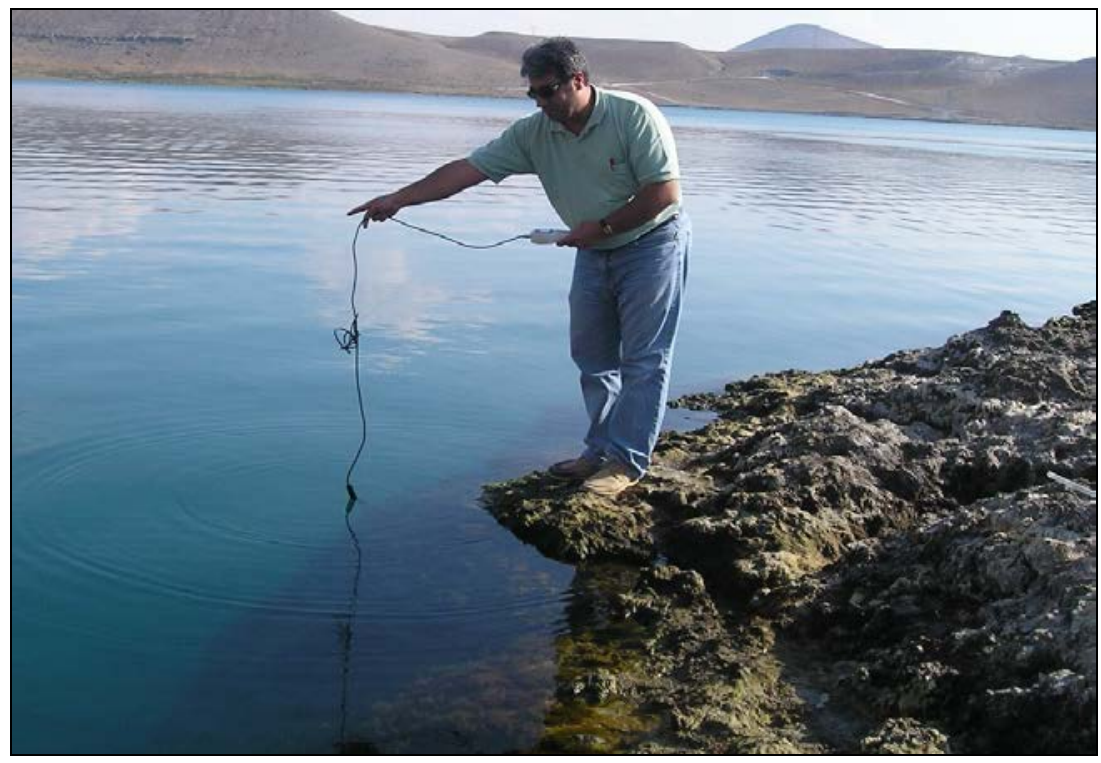

Figure 2: Sampling station in Acı Lake.

\section{Data analysis}

The statistical analysis programme SPSS 15 was used to carry out statistical calculations. One-way ANOVA post-hoc tests (Duncan) were used to determine the differences between seasons and stations in the samples of water and to determine the differences between tissues taken from the fish samples.

\section{RESULTS AND DISCUSSION}

According to the results of the analyses done in the water, without taking into consideration the difference of season and stations, the average values of heavy metal concentrations for $\mathrm{Cr}, \mathrm{Cu}$, and Ni were found to be $0.10 ; 0.11$; and $0.13 \mathrm{mg} \mathrm{l}^{-1}$ respectively per year. Cd and Co metals were not found in any station in any season in this study. In the following tables, the seasonal station averages (Seasonal Averages, Tab. 1) and station annual averages (Stational Averages, Tab. 1) of the identified metals are given.

The following parameters are made use of in determining the quality of the lake's water: $\mathrm{Cr}, \mathrm{Cu}$ and $\mathrm{Ni}$ were measured as heavy metals in this study. Although the value of these elements is higher in some months than others, as shown in figure 3, on average these heavy metals were present at a concentration of approximately 0-0.2 mg/l. As compared with each other, every third metal is high at the same time. Each of them has different peak months. Quality regulations for potable water permit levels of Ni with $\mathrm{Cr}$ up to a maximum of $0.1 \mathrm{mg} / \mathrm{l}$ and $\mathrm{Cu}$ up to $1.3 \mathrm{mg} / \mathrm{l}$. This value is slightly higher in surface waters of high quality (Yskyy, 2012). Measured values of $\mathrm{Cr}$ under this limit are also close to the values of other metals, and close to the maximum limit. These findings indicate that the contamination of water in Ac1 Lake is not very great, indicating that heavy metal pollution is not a serious issue. 

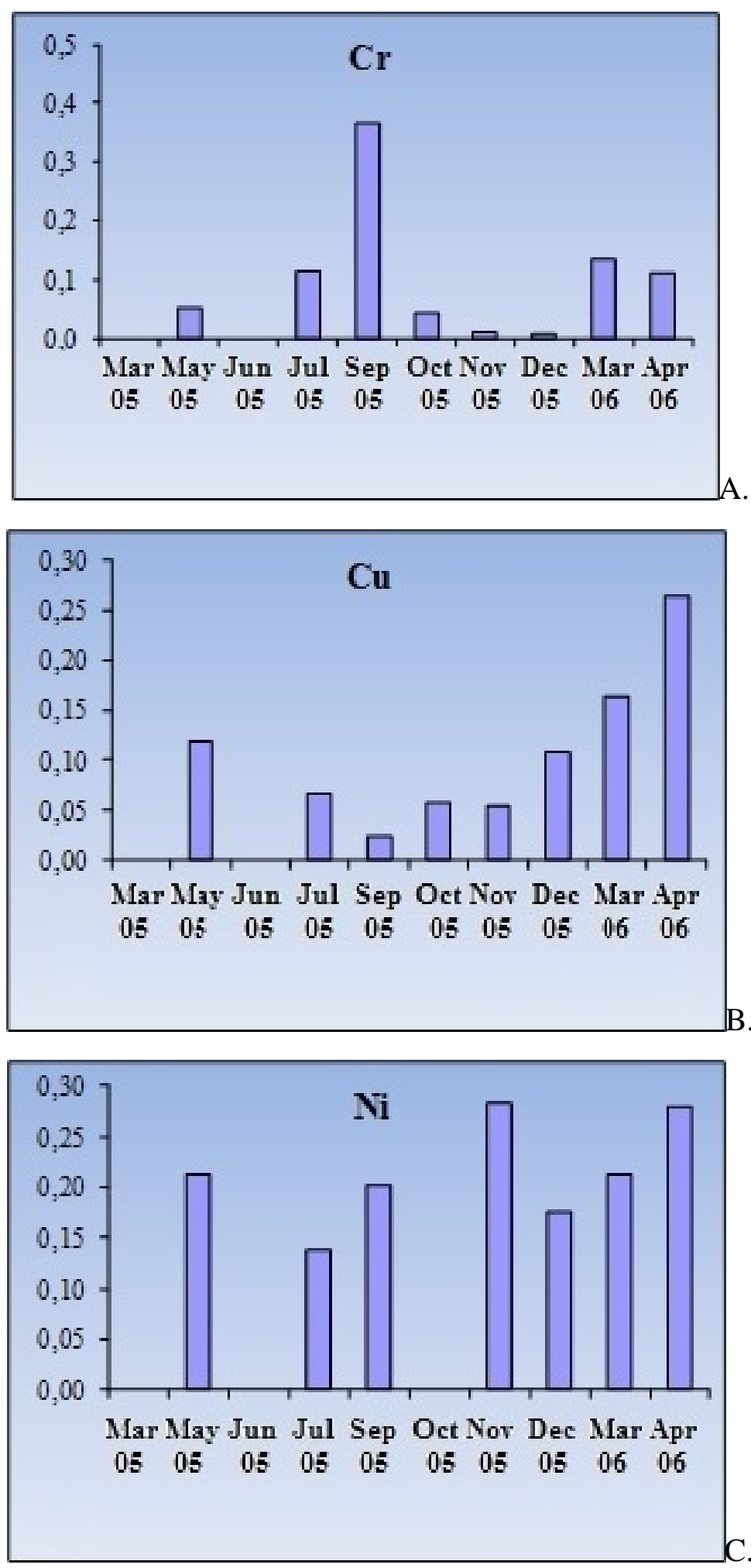

Figure 3: The levels of heavy metals in Ac1 Lake. 
Table 1: The monthly average values of Ac1 Lake's water's physical and chemical characteristics.

\begin{tabular}{|c|c|c|c|c|c|c|c|c|c|c|c|}
\hline Date & 듄 & હે & $\stackrel{\Xi}{\Xi} \stackrel{\circ}{ٍ}$ & 곸용 & 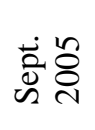 & பூ & 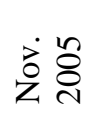 & نٌ & 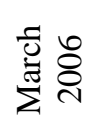 & 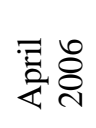 & $\begin{array}{l}\stackrel{0}{0} \\
\stackrel{0}{0} \\
\stackrel{0}{2}\end{array}$ \\
\hline $\mathrm{pH}$ & 7.9 & 7.7 & 7.5 & 7.7 & 7.7 & 7.6 & 7.7 & 7.7 & 7.8 & 7.9 & 7.7 \\
\hline $\begin{array}{c}\text { Dissolved } \\
\text { oxygen } \\
\left(\mathrm{mg} \mathrm{O}_{2} / \mathrm{l}\right) \\
\end{array}$ & 0.75 & 0.73 & 0.7 & & 0.05 & 0.2 & 0.24 & & 0.21 & 0.23 & 0.34 \\
\hline $\begin{array}{l}\text { Muddiness } \\
\text { (NTU) }\end{array}$ & 6.28 & 6.53 & 2.66 & 3.71 & 8.87 & 2.82 & 1.61 & 3.55 & 11.53 & 5.4 & 5.82 \\
\hline TSS (mg/l) & 209 & 535 & 775 & 50 & 22 & 5 & 390 & 555 & 299 & 235 & 281 \\
\hline TSM (mg/l) & & 79.190 & 73.718 & 81.668 & 70.410 & 74.748 & 13.447 & 73.540 & 70.073 & 69.900 & 81.761 \\
\hline $\begin{array}{l}\text { Oil and } \\
\text { grease } \\
(\mathrm{mg} / \mathrm{l})\end{array}$ & 765 & 1,123 & 3,632 & 970 & 3,819 & 3,870 & & 4,053 & 629 & 821 & 2,154 \\
\hline $\begin{array}{c}\text { Acidity } \\
\text { (mg/l) }\end{array}$ & $\begin{array}{c}103.1 \\
2 \\
\end{array}$ & 182.50 & 115.00 & 16,750 & 19,000 & 24,750 & 35,750 & 19,750 & 20,500 & 15,500 & 52,609 \\
\hline $\begin{array}{c}\text { Alkalinity } \\
(\mathrm{mg} / \mathrm{l})\end{array}$ & $\begin{array}{c}103.7 \\
5\end{array}$ & 172.50 & 165.00 & 56,250 & 40,250 & 71,000 & 71,000 & 41,000 & 19,000 & 14,250 & 66.594 \\
\hline $\begin{array}{c}\mathrm{Ca}^{++} \\
\text {Solidity } \\
\text { (mg/l) }\end{array}$ & $\begin{array}{c}18,12 \\
5\end{array}$ & 40,625 & 40,625 & 11,125 & 15,500 & 11,625 & 17,125 & 12,000 & 12,875 & 13,750 & 17,703 \\
\hline $\begin{array}{l}\text { T. Solidity } \\
(\mathrm{mg} / \mathrm{l})\end{array}$ & $\begin{array}{c}61,87 \\
5\end{array}$ & 68,125 & 42,500 & 28,500 & 34,250 & 25,375 & 93,125 & 24,625 & 26,375 & 28,375 & 45,266 \\
\hline $\begin{array}{c}\text { Chloride } \\
\text { (mg/l) }\end{array}$ & $\begin{array}{c}286.8 \\
7 \\
\end{array}$ & 32,500 & 6,250 & 6,625 & 49,250 & 32,500 & 72,000 & 85,000 & 33,250 & 42,250 & 79,203 \\
\hline $\mathrm{SO}_{4}(\mathrm{mg} / \mathrm{l})$ & $\begin{array}{c}101.0 \\
1\end{array}$ & 2,016 & 10,887 & 6,855 & 11,694 & 2,981 & 51,411 & 20,565 & 12,298 & 4,032 & 25,751 \\
\hline $\begin{array}{l}\text { Org. Subst. } \\
(\mathrm{mg} / \mathrm{l})\end{array}$ & 2,625 & 1,625 & 1,750 & 1,500 & 3,625 & 1,625 & 1,100 & 4,225 & 688 & 1,050 & 2,070 \\
\hline $\begin{array}{c}\text { COD } \\
(\mathrm{mg} / \mathrm{l}) \\
\end{array}$ & $\begin{array}{c}108.0 \\
0 \\
\end{array}$ & 40,000 & 92,000 & 1,600 & 96,600 & 140.00 & 108.00 & 76,000 & 14,400 & 164.00 & 93,375 \\
\hline $\begin{array}{c}\text { BOD } \\
(\mathrm{mg} / \mathrm{l})\end{array}$ & & 21.04 & 2.47 & & 14.66 & 7.75 & 1.25 & & 2.5 & 3.5 & 8.45 \\
\hline $\begin{array}{l}\mathrm{NO}_{3}-\mathrm{N} \\
(\mathrm{mg} / \mathrm{l})\end{array}$ & 0.25 & 0.05 & 0.08 & 0.02 & 0.02 & 0.16 & 0.02 & 0.02 & 0.09 & 0.03 & 0.08 \\
\hline $\begin{array}{c}\mathrm{NH}_{3^{-}} \\
\mathrm{N}(\mathrm{mg} / \mathrm{l})\end{array}$ & 3.2 & 22.16 & 29.94 & 13.92 & 11.9 & 15.27 & 10.18 & 15.72 & 15.12 & 11.38 & 13.12 \\
\hline $\mathrm{TP}(\mathrm{mg} / \mathrm{l})$ & 2.46 & 0.21 & 0.45 & 0.02 & 0.01 & 0.14 & 0.02 & 0.01 & 0.07 & 0.05 & 0.37 \\
\hline $\begin{array}{c}\text { Chl-a } \\
\left(\mu \mathrm{g} / \mathrm{m}^{3}\right)\end{array}$ & 4.67 & 5.14 & 8.78 & 3.74 & 0.56 & 79.43 & 1.87 & 12.15 & 23.83 & 2.24 & 16.24 \\
\hline $\mathrm{Cr}(\mathrm{mg} / \mathrm{l})$ & & 0.05 & & 0.12 & 0.36 & 0.04 & 0.01 & 0.01 & 0.13 & 0.11 & 0.1 \\
\hline $\mathrm{Cu}(\mathrm{mg} / \mathrm{l})$ & & 0.12 & & 0.07 & 0.02 & 0.06 & 0.06 & 0.11 & 0.16 & 0.26 & 0.11 \\
\hline $\mathrm{Ni}(\mathrm{mg} / \mathrm{l})$ & & 0.21 & & 0.14 & 0.2 & 0 & 0.28 & 0.18 & 0.21 & 0.28 & 0.19 \\
\hline
\end{tabular}

The solubility of a number of gases such as oxygen changes with temperature. Ac1 Lake is subject to significant variations in temperature (Tab. 4). In the summer, where there are high temperatures, oxygen solubility decreases at the same time as increased biological activity causes the use of an enormous amount of oxygen especially in surface waters, sometimes leading to oxygen depletion. As a result of measurements performed in the Ac1 Lake, oxygen depletion has been identified during the period of highest temperature, in July (3rd station). The lowest temperature was measured at the third and fourth stations in December. Measurements could not be taken in January and February because the lake is completely frozen. The measured temperature range is necessary to maintain the aquatic ecosystem of the lake. 
The hydrogen ion concentration is an important parameter for water resources. The range of hydrogen ion concentration suitable for biological life is quite narrow: a $\mathrm{pH}$ value between four to nine is required for the survival of life in the water. The majority of natural water is slightly alkaline due to carbonates and bicarbonates. The water sampled from Ac1 Lake falls in the neutral and very slightly alkaline $\mathrm{pH}$ range ( $\mathrm{pH}$ seven to eight, Fig. 4). In May and June (2005) both acidity and alkalinity are quite high. This situation in the neutral $\mathrm{pH}$ condition indicates that there is more mineral content as well as dissolved carbonate present, giving the water a high buffering capacity.

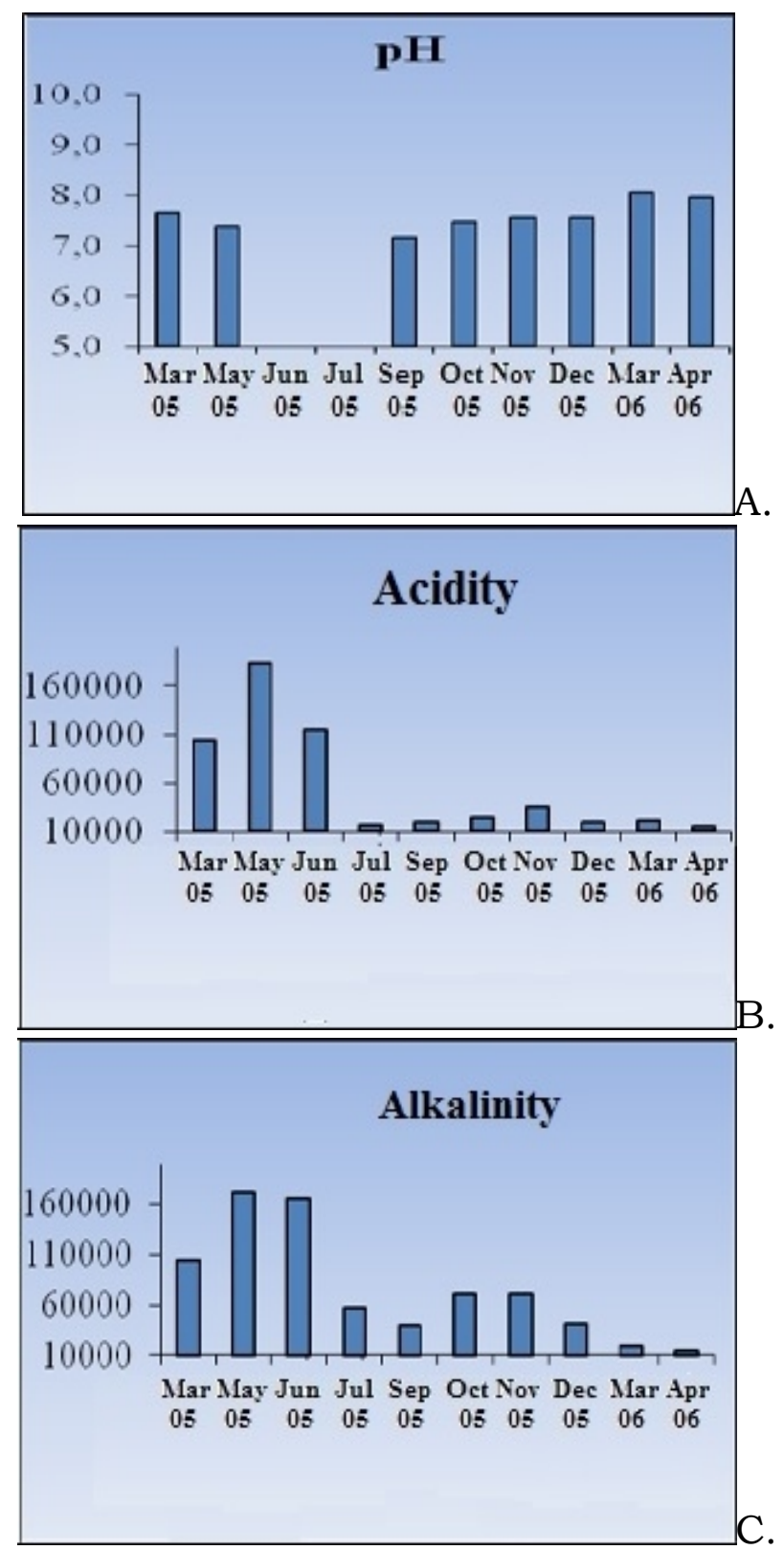

Figure 4: The $\mathrm{pH}$ values of Ac1 Lake. 
Aerobic microorganisms in water and other aquatic organisms produce energy by utilizing oxygen, and they need access to appropriate levels of oxygen in accessible formats, such as dissolved oxygen. In lake Ac1 dissolved oxygen (DO) values are less than one $\mathrm{mg} / \mathrm{l}$ when sampled all months (Fig. 5). This situation affects adversely the quality of the lake water. It must be present at least two $\mathrm{mg} / \mathrm{l}$ dissolved oxygen for aerobic microbial activity.

Table 2: The temperature rates of Ac1 Lake.

\begin{tabular}{|c|c|c|c|c|c|c|c|c|c|c|}
\hline & $\begin{array}{c}\text { April } \\
2006\end{array}$ & $\begin{array}{c}\text { May } \\
2006\end{array}$ & $\begin{array}{c}\text { June } \\
2005\end{array}$ & $\begin{array}{c}\text { July } \\
2005\end{array}$ & $\begin{array}{c}\text { Sept. } \\
2005\end{array}$ & $\begin{array}{c}\text { Oct. } \\
2005\end{array}$ & $\begin{array}{c}\text { Nov. } \\
2005\end{array}$ & $\begin{array}{c}\text { Dec. } \\
2005\end{array}$ & $\begin{array}{c}\text { March } \\
2006\end{array}$ & $\begin{array}{c}\text { April } \\
2006\end{array}$ \\
\hline $\begin{array}{c}\text { 1st } \\
\text { station }\end{array}$ & 11.1 & 14.6 & 24.8 & 25.7 & 21.2 & 17.6 & 8 & 9 & 9.1 & 11.1 \\
\hline $\begin{array}{c}\text { 2nd } \\
\text { station }\end{array}$ & 11.3 & 15.3 & 24.8 & 26 & 23.1 & 18.4 & 9 & 8 & 10.5 & 11.3 \\
\hline $\begin{array}{c}\text { 3rd } \\
\text { station }\end{array}$ & 11.5 & 15.7 & 24.8 & 26.3 & 23.4 & 18.3 & 9 & 7 & 10.2 & 11.5 \\
\hline $\begin{array}{c}\text { 4th } \\
\text { station }\end{array}$ & 11.1 & 14.8 & 21 & 25.7 & 23 & 18 & 8 & 7 & 9.2 & 11.1 \\
\hline & $\begin{array}{c}\text { April } \\
2006\end{array}$ & $\begin{array}{c}\text { May } \\
2006\end{array}$ & $\begin{array}{c}\text { June } \\
2005\end{array}$ & $\begin{array}{c}\text { July } \\
2005\end{array}$ & $\begin{array}{c}\text { Sept. } \\
2005\end{array}$ & $\begin{array}{c}\text { Oct. } \\
2005\end{array}$ & $\begin{array}{c}\text { Nov. } \\
2005\end{array}$ & $\begin{array}{c}\text { Dec. } \\
2005\end{array}$ & $\begin{array}{c}\text { March } \\
2006\end{array}$ & $\begin{array}{c}\text { April } \\
2006\end{array}$ \\
\hline $\begin{array}{c}\text { 1st } \\
\text { station }\end{array}$ & 11.1 & 14.6 & 24.8 & 25.7 & 21.2 & 17.6 & 8 & 9 & 9.1 & 11.1 \\
\hline
\end{tabular}

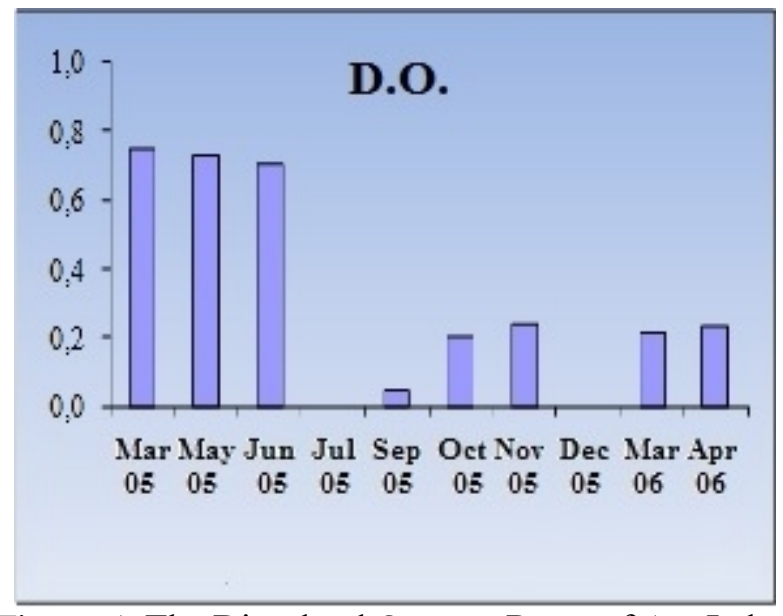

Figure 5: The Dissolved Oxygen Rates of Ac1 Lake.

Chemical oxygen demand (COD) is one of the most important parameters to use for determining the degree of pollution of domestic and industrial waste water. Although biochemical oxidation occurs very fast in some organic matter, the amount of organic matter is measured as chemical (which may be oxidized in an acidic environment with dichromate) in chemical oxidation. COD is one of the most commonly used parameters in studying environmental pollution. The average domestic wastewater COD values are between 400-600 $\mathrm{mg} / \mathrm{l}$. The low level of DO indicates pollution in Ac1 Lake water. Therefore, high COD values are also expected, which is indeed observed in the samples (Fig. 6), with samples indicating a high level of organic pollution in Ac1 Lake. 


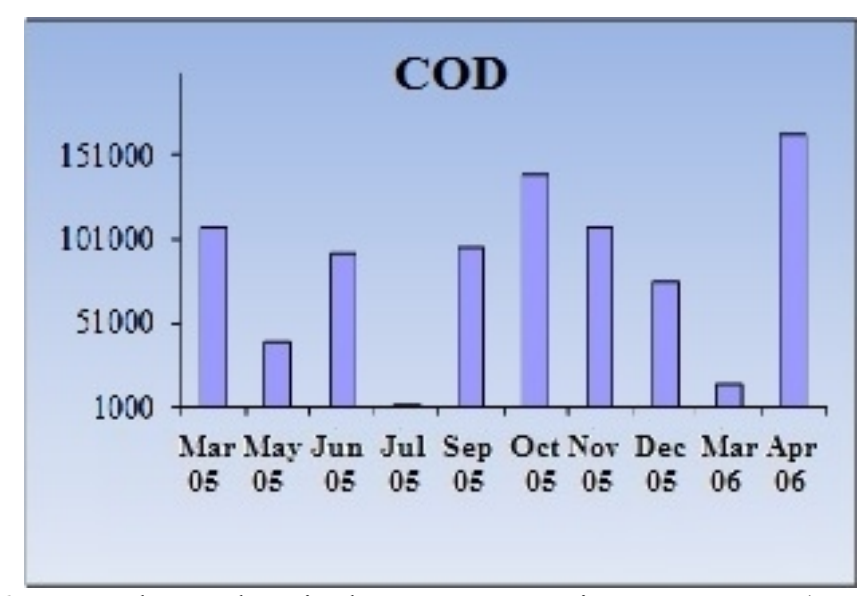

Figure 6: Ac1 Lake's Chemical Oxygen Requirement Rates (COD mg/l).

Biochemical oxygen demand (BOD) is the amount of oxygen which necessary to stabilize the bacteria breaking down organic substances under aerobic conditions. Five-day BOD is the most frequently used parameter to identify organic contamination in waste water and surface water samples. BOD is based on aerobic oxidation and it a living test (bioassay) using organic nutrient substances and measuring the consumption of oxygen by mixed microorganism at $20^{\circ} \mathrm{C}$. In domestic wastewater, the BOD/COD ratio is approximately 0.60.65. Despite its widespread use, there are some disadvantages of this method; it requires a bacterial vaccine for species with high levels of activity and which are accustomed to waste water, pre-treatment requirements for toxic wastewaters, a requirement for nitrification inhibition, only the biodegradable material can be measured, and it takes a long time in comparison with other tests. Although BOİ data could not be obtained for all samples, those values that were obtained indicate that the $\mathrm{BOD} / \mathrm{COD}$ ratio is incompatible with domestic water (Fig. 7). BOD values were observed to be quite low compared to COD. This is a sign that it is a bit different from the type of biodegradable organic material type. In this case, contamination is a more serious problem.

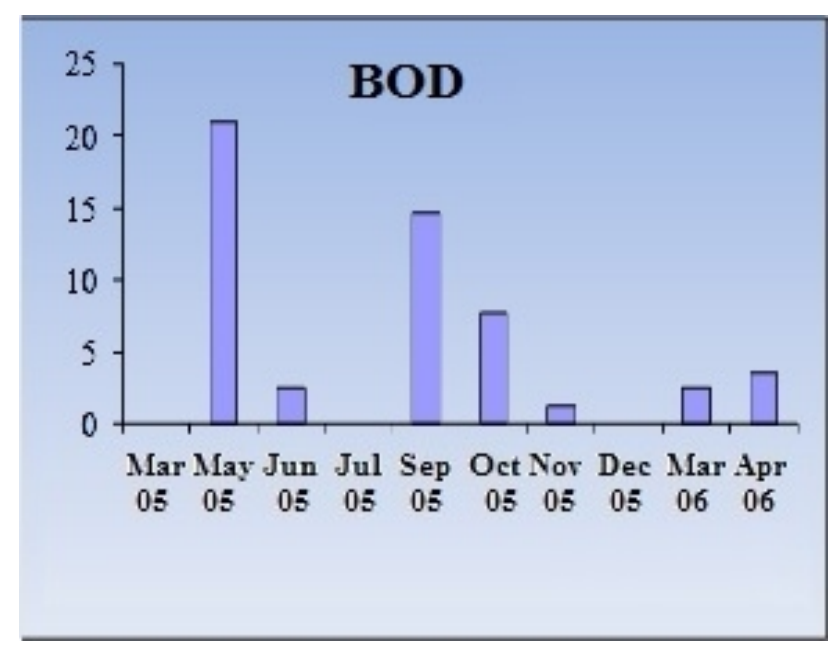

Figure 7: Acı Lake's Biochemical Oxygen Requirement Rates (BOD mg/l). 
Suspended or dissolved materials in natural water and waste water are called solids. Water containing a high percentage of solids is not used for drinking water or for industrial purposes. Based on the results reported already in this paper, a high value of the CDM is to be expected in Ac1 Lake water. It was determined from the acidity and alkalinity data that the amount of dissolved mineral and ions in the water is high. Accordingly, the total solid (TS) level is high. Total dissolved solids data are presented in the next section along with levels of sulphate and chloride values which are salinity indicators and may help explain the findings. Based on the geological structure of Ac1 Lake and the environment, it is to be expected that salinity and TSM are high.

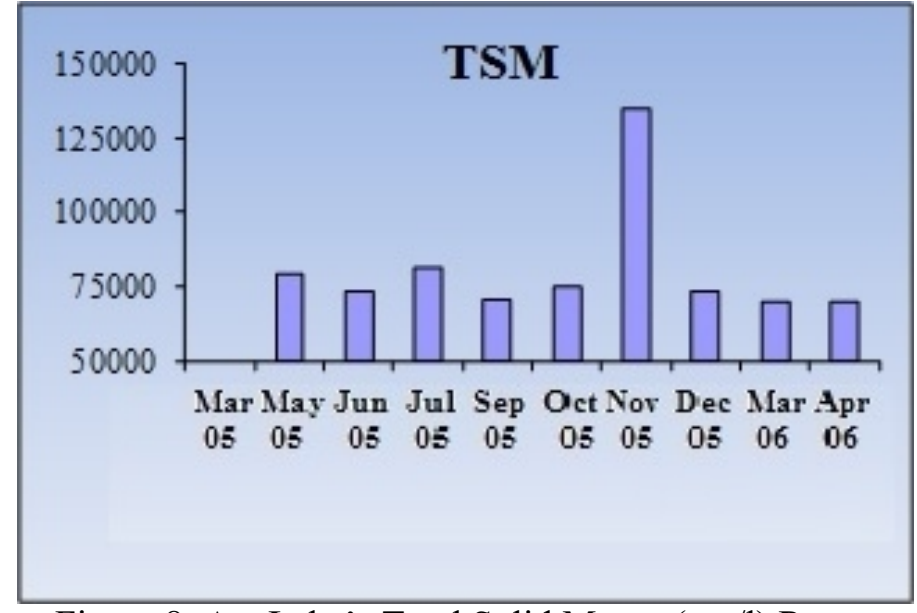

Figure 8: Acı Lake's Total Solid Matter (mg/l) Rates.

When figures 7 and 8 are evaluated together, it is seen that the total solids in the lake form a very small portion of the Total Suspended Solids (TSS). TSS values are an approximate value of domestic wastewater and this property is the result of the combination of the underlying geology of the lake, a travertine structure, and possible pollution status. In spring and autumn this value can be higher than in other seasons due to vertical mixing in lake water, eliminating stratification and evenly distributing TSS throughout the lake.

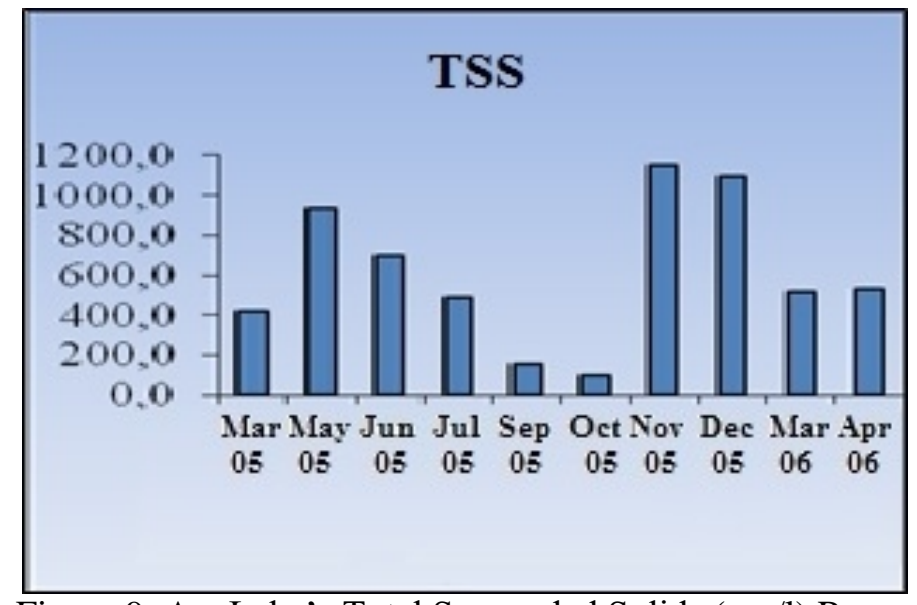

Figure 9: Ac1 Lake's Total Suspended Solids (mg/l) Rates. 
Colloidal substances in water and suspended solids deposition create turbidity. It is measured by the turbid meter. Natural water is never as clear as pure water, because there are dissolved substances, microscopic creatures, suspended particles and so forth. Turbidity values of samples from Ac1 Lake are quite low, approximately in the range of 2-11 NTU (Fig. 10). In line with previous findings, dissolved solids pollution seems to be higher than solid pollution.

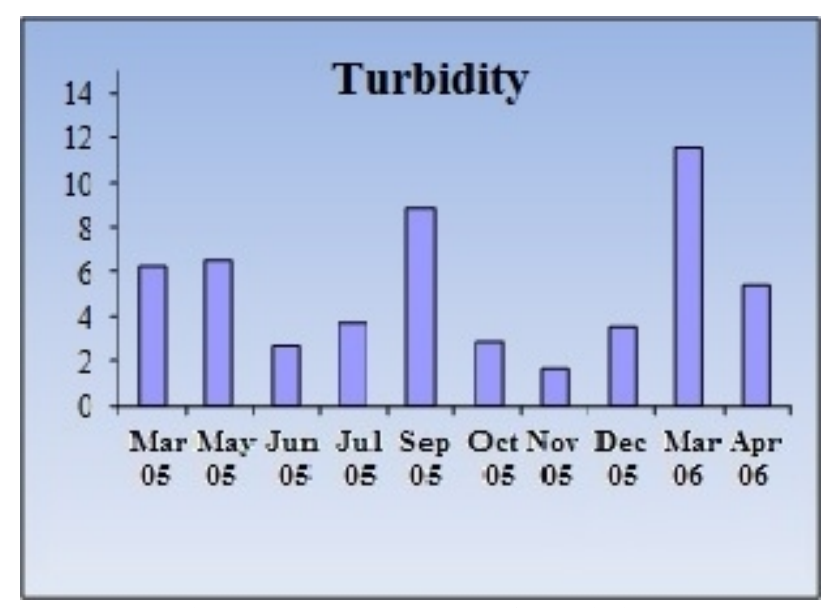

Figure 10: The rates of turbidity.

Oil and grease both have limited solubility in water and a tendency to leave the water phase, making these two types of substances important. The oil-grease is a parameter typically measured in wastewater and sewage treatment plants. Normally oil-grease is present in surface waters due to unexpected causes, and therefore it does not typically exist among the analyzed parameters in routine analysis. But, considering the levels of organic matter and mineral contaminants described in the above sections in Ac1 Lake, this parameter was evaluated for verification purposes. As shown in figure 11, values of oil-grease vary from $630 \mathrm{mg} / \mathrm{l}$ to over $4,000 \mathrm{mg} / \mathrm{l}$. Values of DO are low, generally have higher concentrations of organic substances especially that high in the months make strong judgment of wastewater pollution which is nondomestic origin.

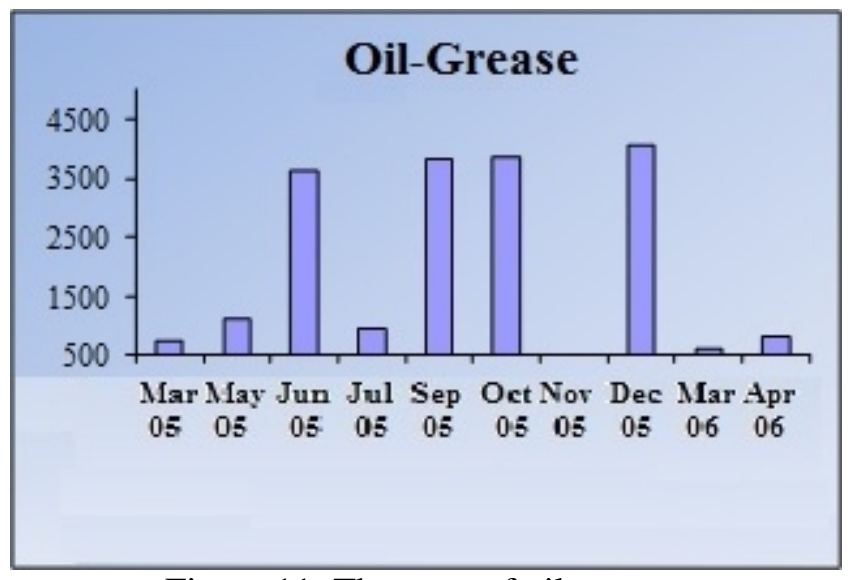

Figure 11: The rates of oil-grease. 
If there is no oxygen or nitrate in a rich environment, then anaerobic bacteria tend to dominate in breaking down organic substances. This typically produces sulfate ions and bacteria benefit from the oxygen that is produced in the process. Consequently, sulphate ions combine with hydrogen ions, creating hydrogen sulfide, a source of many problems such as corrosion and smell. Sulfate anion is one of the most common forms of sulfur in fresh waters, as it comes from sulphate-rich sediments eroded by rain. However, sulfate is not very common in surface water. The lack of a sufficient supply of sulphate in water inhibits phytoplankton growth, and therefore biological yield decreases. As shown in figure 12 the highest sulphate values in Acı Lake were observed in spring (March) and autumn (November). The maximum limit of sulphate in water for human consumption is $250 \mathrm{mg} / \mathrm{l}$, so the results presented here indicate that the maximum measured values of sulfate is not surprising given the mineral content and the high amount of organic pollution. On the other hand, soluble sulphate depends on the structure of rocks in the region, which is known to contain rocks with permanent hardness components such as ${ }^{2+}$ bivalent $\mathrm{Ca}$ and $\mathrm{Mg}$ ions. These are known to bind to ions such as sulfate and chloride, so an excess of sulfate indicates the presence of these compounds.

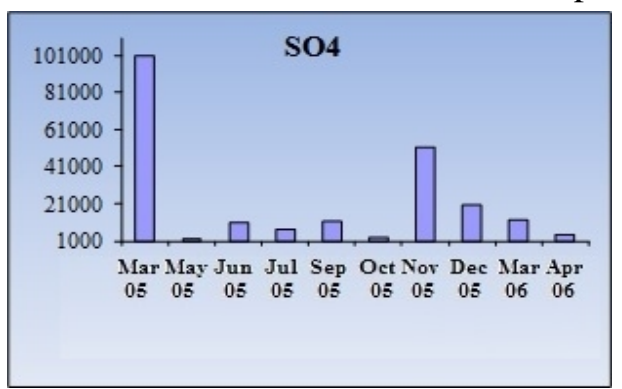

Figure 12: Ac1 Lake's Sulfate concentration (mg/l).

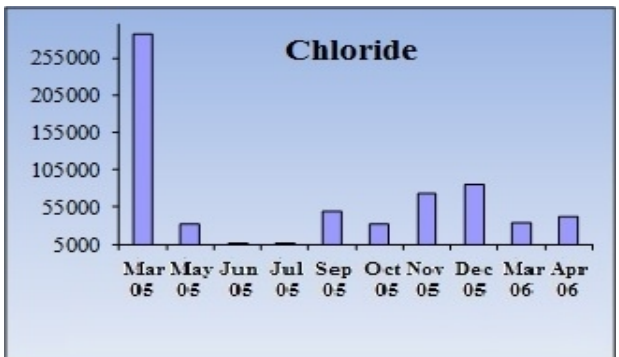

Figure 13: Ac1 Lake's Chloride (mg/l) Rates.

Chloride ions $(\mathrm{Cl})$ are found in almost all natural waters in various concentrations. Because chloride is readily soluble in water, there are often many chloride salts present in natural water. Chloride can also come from waste water. While concentrations higher than 250 $\mathrm{mg} / \mathrm{l}$ chloride in drinking water is not allowed, chloride may be allowed up 2,000 mg/l in water used for other purposes. Chloride is closely related to salinity and electrical conductivity. As the chloride concentration increases, these other parameters will also increase. High levels of salinity in water resources used for potable water are not ideal, because treatment is costly. Chloride values in Ac1 Lake are high, with the highest value measured in March 2005, as $2.9 * 105 \mathrm{mg} / \mathrm{l}$ (Fig. 13). All chloride values were over 2,000 $\mathrm{mg} / \mathrm{l}$ in the period studied. The average chloride value was 55,000 mg/l. This situation of excess salinity is in line with the region's underlying geological structure and mineral content. While supporting the existence of pollution, it also points to the permanent hardness components of the water from the rocks. 
The water hardness occurs largely as the result of contact with soil and rocks. Hard water has several drawbacks: hard water requires much soap usage by preventing the soap foaming and it leads to the formation of scales on the inner walls of pipes at high temperatures. When it comes to the total hardness of water, this is influenced by a number of alkaline earth ions in water, and also strontium and barium ions. Water is considered "hard" when it contains over $300 \mathrm{mg} / \mathrm{l} \mathrm{CaCO}_{3}$. Hardness is regarded as the most important component of the Ca ions when considering rock structures. $\mathrm{C}$ hardness and total hardness were measured separately to determine how much of the hardness in Ac1 Lake is the result of $\mathrm{Ca}$ in samples. It was found that $\mathrm{Ca}$ varied from $11,000 \mathrm{mg} / \mathrm{l} \mathrm{CaCO}_{3}$ up to $41,000 \mathrm{mg} / \mathrm{CaCO}_{3}$ with an average value of $24,000 \mathrm{mg} / \mathrm{l} \mathrm{CaCO}_{3}$ and a maximum value of $94,000 \mathrm{mg} / \mathrm{CaCO}_{3}$ (Fig. 13). The most important result from measuring this parameter is that although the lake water is very hard, the majority of the hardness is not from Ca, except in the months of May and June. Concentrations of strontium, an ion which also causes hardness, are also present in high concentrations. When given the above data on acidity and alkalinity, it becomes clear that water hardness in lake Aci is caused evenly by both carbonate hardness (temporary hardness caused by $\mathrm{Ca}$ ) and non-carbonate hardness (permanent hardness caused by an excess of chloride and sulphate forms).
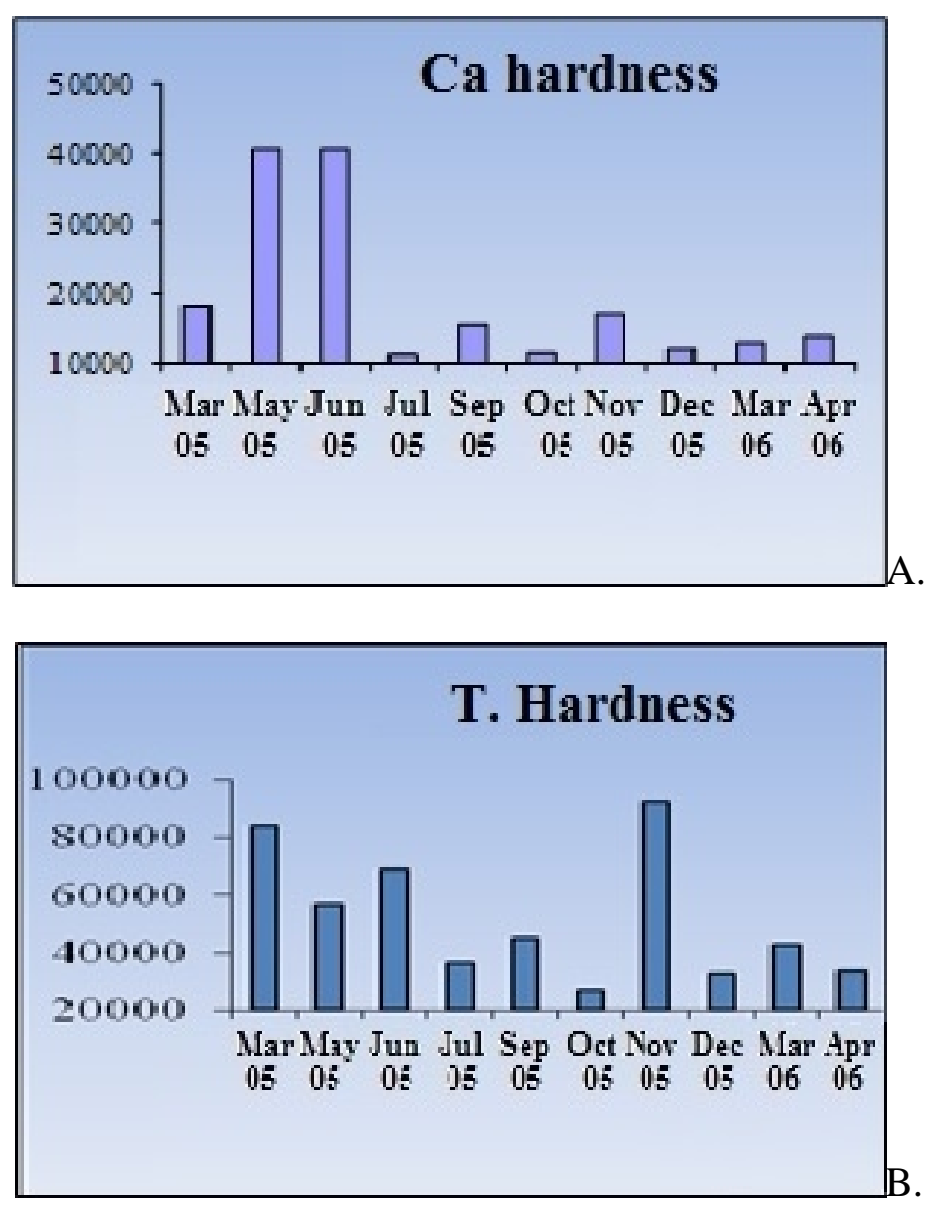

Figure 14: Ac1 Lake's Total Hardness $\left(\mathrm{mg} \mathrm{CaCO}_{3} / \mathrm{l}\right)$ Rates. 
Many of the nutrients involved in water pollution, especially nitrogenous substances, are priority pollutants. Nitrogen has a natural circulation in water sources, in the atmosphere, in plants and animals, and it forms different compounds. It is a nutrient material which is necessary for the survival and reproduction of almost all living cells. Nitrogen with phosphorus is very important as a food (nutrient) source in microbiological and algal growth in water sources. Algal growth can occur undesirably in water supplies contaminated with excess nutrients. Three types of water-soluble nitrogen, namely ammonium, nitrate and nitrite, have environmental importance. Nitrite $\left(\mathrm{NO}_{2}\right)$, because it is a temporary phase ion, is often minimally present in water. Nitrate $\left(\mathrm{NO}_{3}\right)$ has been the most researched of the nitrogen forms, yet it is one of the most difficult ions to measure. Nitrogen species indicate both the presence of contamination and whether it is recent or old pollution. When wastewater is newly discharged, organic nitrogen is most common. Over time, this turns into first ammonia nitrogen, and then if the environment remains aerobic, into nitrite, then into nitrate. This transformation is achieved by autotrophic bacteria using DO in the environment, which causes the DO concentration to decrease. Ammoniacal nitrogen values are relatively high compared to the concentration of nitrate in Ac1 Lake (Figs. 14a-b). Hence, the results obtained indicate that the pollution of the lake is new, because otherwise anoxic conditions in the lake would predominate (DO to be close to zero), and denitrification would take place efficiently.

Total phosphorus found was high (TP) only in March (2005). At other times it was very low (Fig. 15C). Because many of the other parameters were also significantly higher in the same month, in March 2005, this indicates the possibility of an immediate discharge of waste water into Acı Lake. The highest TP is about $2.5 \mathrm{mg} / \mathrm{l}$, but the average was observed between $0-0.5 \mathrm{mg} / \mathrm{l}$. When compared with nitrogen data, to prevent an increase in the level of algal growth, there needs to be an adequate level of TPI. Chlorophyll A values are generally low, peaking in October 2005 (Fig. 15D). This can be explained by algal blooms occurring in the autumn. In contrast, the lake is not very rich in algal biomass. These results indicate that at present, there is no case of eutrophication but that there is a risk of it in the future.

\section{CONCLUSIONS}

Temperatures in Ac1 Lake fall within a suitable temperature range to maintain the vibrant life of aquatic systems. Both acidity and alkalinity are quite high. With a neutral $\mathrm{pH}$, this situation indicates that water soluble carbonates, as well as the mineral content, are high in concentration, indicating a high buffering capacity of the water. It is seen that the TSS forms only a small portion of the total solids. TSS values are approximately the same value as domestic wastewater and it confirms that there are pollution problems in the lake. Turbidity values of samples from Ac1 Lake are low, approximately in the range of 2-11 NTU. Solid analysis confirms that pollution is present.

Measured values of chloride and sulphate are in line with the other observations of excess mineral content and support the presence of contamination. However, the underlying geology of the region, consisting of soluble rocks in natural waters, are also important in understanding the measures of permanent hardness of the lake water, and depends on which Ca and $\mathrm{Mg}^{2+}$ ion valences are formed with sulphate and chloride ions. High levels of sulphate ions indicate to the presence of these compounds. Having extremely high level of hardness in water samples supports this finding. When acidity and alkalinity are assessed with other measures of water quality, it indicates that Lake Aci experiences both carbonate hardness (temporary hardness) and non-carbonate hardness (permanent hardness) from high levels of chloride and sulphate. 

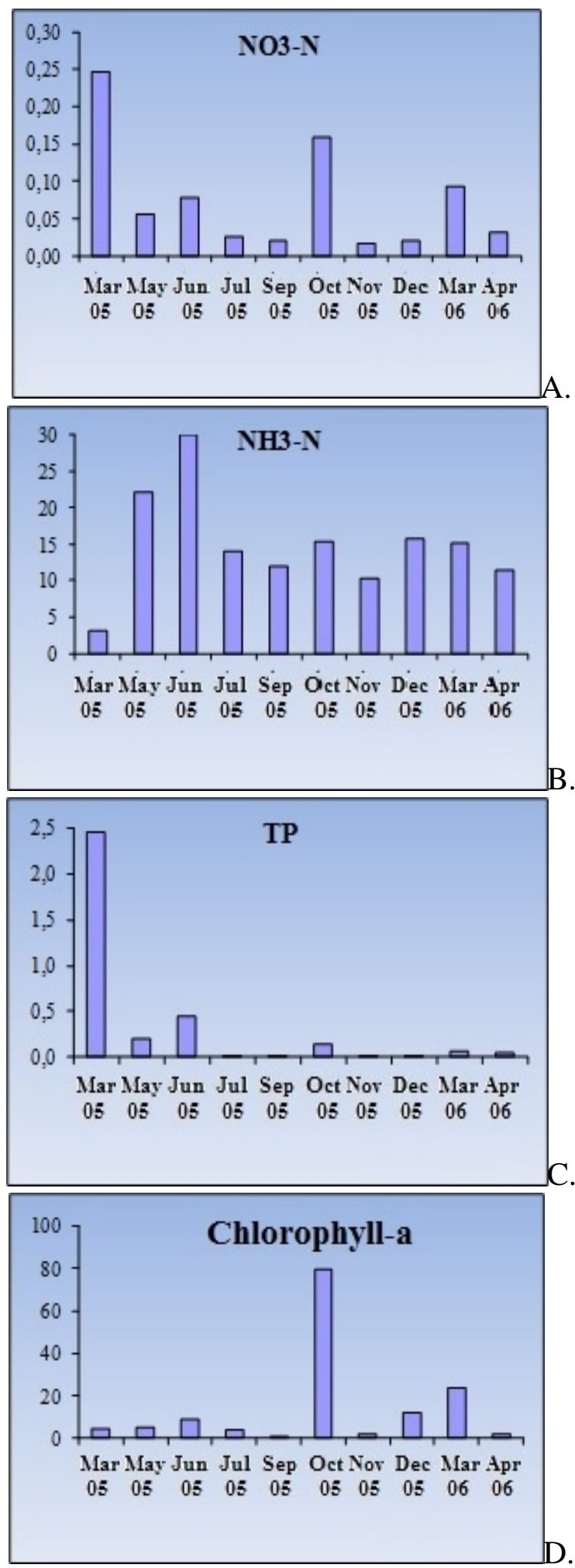

Figure 15: Concentrations of nitrogen, phosphorus and chlorophyll in Ac1 Lake. 
Dissolved Oxygen values are less than one $\mathrm{mg} / \mathrm{l}$ when sampled across all months. This situation adversely affects the quality of the lake water. DO must be present in concentrations of at least two mg/l dissolved oxygen for aerobic microbial activity to take place. On the other hand, samples indicate quite high COD levels above the average 400-600 mg/l permitted in domestic waste water - indicating organic pollution in Ac1 Lake. There were very low BOD values observed compared to COD. This indicates that the type of biodegradable organic matter is slightly unusual, and may indicate a more serious problem. Normally oil-grease is not expected in surface waters, and does not form part of routine water quality analyses. But, considering the organic matter and mineral contaminants as described in the above sections in Ac1 Lake, this parameter was evaluated for verification purposes. Values of DO are low, and generally reflect higher concentrations of organic substances, strongly suggestive of wastewater pollution which has a non-domestic origin. Ammoniacal nitrogen values are relatively high compared to the nitrate nitrogen in Ac1 Lake (15A-B). Hence, results were obtained that the pollution of the lake is new or anoxic conditions in the lake (DO to be close to zero), denitrification takes place in an efficient manner. In the other direction it was not very rich algal biomass lake. At present, there is no case of eutrophication but there is a high potential of it occurring in the future without remediation of the existing water quality and management.

There are several options for the future management of lake Ac1, notably the need for afforestation, not only to control the erosion there, but also to provide shelter, reproduction opportunities and nourishment possibilities to the members of that particular area's fauna. Thus, it is recommended that suitable bushes and trees are planted in the area, to reduce the risk of pollution.

\section{ACKNOWLEDGEMENTS}

This work is supported by The Research Foundation of Selcuk University (project number: 14401085). 


\section{REFERENCES}

1. Abdel-Baky T. E., Hagras A. E., Hassan S. H. and Zyadah M. A., 1998 - Environmental Impact Assessment of Pollution in lake Manzalah, I, Distribution of Some Heavy Metals in Water and Sediment, Journal of the Egyptian-German Society of Zoology, 26, B, 25-38.

2. Akköz C. and Yılmaz B., 2009 - Studies on Suğla Lake (Seydişehir/Konya) Benthic Algae, Faculty of Science, Journal of Science, 33, 51-59.

3. Al-Saadi H. A., Al-Lami A. A., Hassan F. A. and Al-Dulymi A. A., 2002 - Heavy Metals in Water, Suspended Particles, Sediments and Aquatic Plants of Habbaniya Lake, Iraq, International Journal of Environmental Studies, 59, 5, 589-598.

4. Baron J., Legret M. and Astruc M., 1990 - Study of Interactions Between Heavy Metals and Sewage Sludge: Determination of Stability Constants and Complexes Formed with $\mathrm{Cu}$ and $\mathrm{Cd}$, Environmental Technology, 11, 151-162.

5. Bănăduc D., Rey S., Trichkova T., Lenhardt M. and Curtean-Bănăduc A., 2016 - The Lower Danube River-Danube Delta-North West Black Sea: A pivotal area of major interest for the past, present and future of its fish fauna - A short review, Science of the Total Environment, 545-546, DOI: 10.1016/j.scitotenv.2015.12.05, 137-151.

6. Brinson M. M., Lugo A. E., Brown S., 1981 - Primary productivity, decomposition and consumer activity in freshwater wetlands, Annual Review of Ecology and Systematics, 12, 123161.

7. Cataldo D., Colombo J. C., Boltovskoy D., Bilos C. and Landoni P., 2001 - Environmental Toxicity Assessment in the Paraná River Delta (Argentina): Simultaneous Evaluation of Selected Pollutants and Mortality Rates of Corbicula fluminea (Bivalvia) Early Juveniles, Environmental Pollution, 112, 379-389.

8. Cid B., Boia C., Pombo L. and Rebelo E., 2001 - Determination of trace metals in fish species of the Ria de Averiro (Portugal) by electrotermal atomicabsorptionspectrometry, Food Chemistry, 75, 1, 93-100.

9. De Grot R. S., Stuip M. A. M., Finalyson C. M. and Davidson N., 2006 - Valuing Wetlands: Guidance for Valuing the Benefits Derived from Wetland Ecosystem Services, Ramsar Technical Report no. 3/CBD Technical Series no. 27, Ramsar Convention Secretariat, Gland, Switzerland and Secretariat of the Convention on Biological Diversity, Montreal, Canada.

10. Dural M., Göksu M. Z. and Özak A. A., 2007 - Investigation of heavy metal levels in economically important fish species captured from the Tuzla lagoon, Food Chemistry, 102, 415-421.

11. Ercan T., 1987 - Orta Anadolu'daki Senozoyik volkanizması, Maden Tetkik ve Arama Dergisi, 107, 119-140. (in Turkish)

12. Gleick P. H. (ed.), 1993 - Water in crises: A Guide to the World's Freshwater Resources, Oxford University Press, 13-24.

13. Görmez K., 1997 - Environmental Problems and Turkey, Gazi Bookstore Press, 2nd edition, Ankara, 17, 53-56.

14. Güven K., Ozbay C., Ünlu E. and Satar A., 1999 - Acute Lethal Toxicity and Accumulation of Copper in Gammarus pulex (L.) (Amphipoda), Turkish Journal of Biology, 23, 513-522.

15. Hadring J. P. and Whitton B. A., 1978 - Zinc, Cadmium and Lead in Water Sediments and Submerged Plants of the Derwent Reservoir, Northern England, Water Research, 12, 307-316.

16. Hakanson L., 1984 - Metals in fish and sediment from river Kolbacksan water system, Sweden, Archiv für Hyrobiology, 101, 373-400.

17. Karadede H. and Ünlü E., 2000 - Concentrations Heavy Metals in water, sediment and Fish species from Atatürk Dam Lake (Euphrate) Turkey, Chemospher, 41, 1371-1376.

18. Karadede H., Oymak S. A. and Ünlü E., 2004 - Heavy metals in mullet, Liza abu and catfish, Silurus triostegus, from the Ataturk Dam Lake (Euphrates), Turkey, Environment International, 30, 183-188. 
19. Keddy P. A., 1983 - Freshwater wetlands human-induced changes: Indirect effects must also be considered, Environmental Management, 7, 4, 299-302.

20. Odokuma L. O. and Ijeomah S. O., 2003 - Seasonal Changes in the Heavy Metal Resistant Bacterial Population of the New Calabar River, Nigeria, Global Journal of Pure and Applied Sciences, 9, 4, 425-434.

21. Özmen H., Külahçı F., Çukurovalı A. and Doğru M., 2004 - Concentrations of Heavy Metal

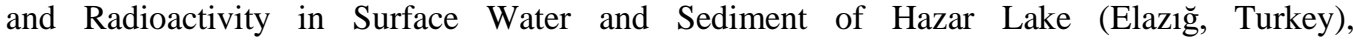
Chemosphere, 55, 401-408.

22. Poons L., 2008 - The explanation of worldwide spread of acid sulphate soils, Transylvanian Review of Systematical and Ecological Research, The Wetlands Diversity, 6, 1-16.

23. Wang L., Xue F., Gao W., Shi J., Sun S., Liu J., Su R., Xie Y., Hai C. and Xiaojia L., 2016 The effects of enclosing land on the physical properties of soil in the loess hill region of Ordos, Transylvanian Review of Systematical and Ecological Research, The Wetlands Diversity, 18.3, 1-14.

24. Yarsan E., Bilgili A. and Türel İ., 2000 - The Heavy Metal Levels in the Mussel (Unio stevenianus krynicki) Samples Taken Out of Van Lake, Turkish Journal of Veterinary and Animal Sciences, 24, 93-96.

25. Zhou H. Y., Cheung R. Y. H., Chan K. M. and Wong M. H., 1998 - Metal Concentrations in Sediments and Tilapia Collected from Inland Waters of Hong Kong, Water Research, 11, 33313340. 